\title{
Typological and Contrastive Features of Russian and English and Translational Transformations
}

\author{
Igor V. Nedjalkov* \\ St. Petersburg State University \\ 7/9 Universitetskaya nab., St. Petersburg, 199034, Russia
}

Received 18.09.2015, received in revised form 06.10.2015, accepted 22.11.2015

The first part presents the main typological and contrastive properties of English and Russian and shows in what way these properties may condition Russian $\rightarrow$ English translational transformations of various types. The second part contains the overview of English correspondences of Russian constructions lacking the canonical subject in the nominative case (impersonal proper, indefinitepersonal, generic-personal, infinitival constructions, etc.) found in the novel "Anna Karenina" written by Leo Tolstoy. In some cases examples from "Crime and Punishment" written by Fyodor Dostoyevsky and plays by Anton Chekhov are also provided. English correspondences of the following Russian impersonal constructions (ICs) are analysed: ICs denoting natural phenomena, ICs denoting physiological states, ICs denoting situations of sense perception, ICs denoting emotions and feelings, ICs expressing modality. The main ways of translating Russian ICs into English are the following: 1) English personal constructions, 2) English constructions involving dummy it, 3) English constructions involving introductory element there, 4) English constructions involving introductory element one.

Keywords: theory of translation, linguistic typology, contrastive linguistics, typological and contrastive properties of English and Russian, translational transformations, impersonal constructions, infinitival constructions, English means of rendering Russian subjectless constructions.

DOI: 10.17516/1997-1370-2015-8-12-2920-2933.

Research area: philology.

\section{Introductory notes}

The paper consists of two parts. The first part briefly presents the main typological and contrastive properties of English and Russian languages and shows in what way these properties may condition Russian $\rightarrow$ English translational transformations (TT) of various types. The second part contains the overview of English correspondences of Russian constructions lacking the canonical subject in the nominative case (e.g. impersonal, indefinite-personal, generic-personal, infinitival, etc.) found in the novel "Anna Karenina" written by Leo Tolstoy [LT] (abbreviations of translators' names of this novel are presented in the end of the paper). In some cases examples from "Crime and Punishment" written by Fyodor Dostoyevsky [FD] and plays by Anton Chekhov [AC] are also provided (names of translators

\footnotetext{
(C) Siberian Federal University. All rights reserved

* Corresponding author E-mail address: igor_nedjalkov@mail.ru
} 
of Dostoyevsky's novel are given in examples (1) and (2); the data was collected both by the author and his post-graduate students). In some cases examples from specialist literature are given in addition [Sovremennyj russkij jazyk, 1999].

For the purposes of this paper I will use the typology of TTs proposed by Leonid Barkhudarov in his book "Jazyk i perevod" (Language and translation) (Barkhudarov, 1975). According to his theory there exist four main types of TTs: 1) permutation of components (change of their positioning); 2) choice of different constructions; 3) addition of components, and 4) omission (deletion) of components. Obviously each type of TTs is represented by numerous subtypes (Barkhudarov 1975, 190-231).

The most interesting enterprise in this case is the comparison of several English translations done by translators in different times (e.g. a century ago vs. recently) and countries (e.g. in Great Britain or USA), cf.

(1) (F. Dostoyevsky. Crime and Punishment)

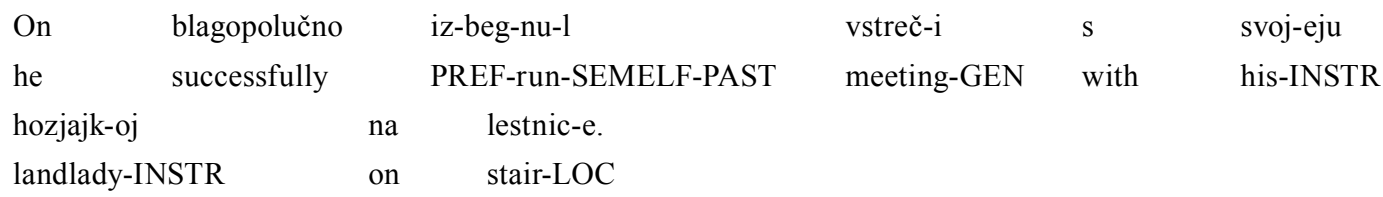

a. He had successfully avoided meeting his landlady on the staircase (C. Garnett);

b. He was lucky to avoid a meeting with his landlady on the stairs (D. Magarshack);

c. He had been lucky enough to escape meeting his landlady on the staircase (J. Katzer);

d. He had succeeded in avoiding an encounter with his landlady on the stairs (D. McDuff);

e. He was fortunate enough not to meet his landlady on the stairs (Anonymous translator; Penguin Popular Classics. London 1997).

(2) (F. Dostoyevsky. Crime and Punishment)

$\begin{array}{llllll}\text { Marmeladov } & \text { rešitel'no } & \text { stuk-nu-l } & \text { kulak-om } & \text { po } & \text { stol-u. } \\ \text { Marmeladov } & \text { resolutely } & \text { strike-SEM- } & \text { fist-INSTR } & \text { on } & \text { table-DAT } \\ & & \text { PAST } & & & \end{array}$

a. Marmeladov struck his fist resolutely on the table (C. Garnett);

b. M. brought down his fist with a bang on the table (D. Magarshack);

c. M. struck the table emphatically with his fist (J. Katzer);

d. M. resolutely hammered his fist down on the table (D. MacDuff);

e. Marmeladoff struck the table with his fist (Anonymous translator; Penguin Popular Classics. London 1997).

(3) (L. Tolstoy. Anna Karenina)

$\begin{array}{lllll}\text { Vsjo } & \text { s-meša-l-o-s' } & \mathrm{v} & \text { dom-e } & \text { Oblonski-x. } \\ \text { Everything } & \text { PREF-mix-PAST-NEUTR- } & \text { in } & \text { house-LOC } & \text { Oblonsky-PL.GEN } \\ & \text { POSTFIX } & & & \end{array}$

a. Everything was in confusion in the Oblonskys' house (C. Garnett);

b. Everything was in confusion in the Oblonskys' household (D. Magarshack); 
c. All was confusion in the Oblonskys' house (Pevear / Volokhonsky);

d. Everything had gone wrong in the Oblonsky household (R. Edmonds);

e. Everything was upset in the Oblonskys' house (L. Maude \& A. Maude);

f. The Oblonsky home was in turmoil (M. Wettlin);

g. Everything at the Oblonskys' was topsy-turvy (J. Carmichael).

In example (2) Russian instrumental object kulakom "with the fist" is rendered by the English direct object in (2a), and in example (3) Russian adverbial of place corresponds to the English subject in (3f).

Several translations of one original text show the degree of variation of language means involved in different construction types.

\section{Typological and contrastive features of English and Russian}

Russian and English differ radically with respect to the main typological features of languages. These features of English and Russian which can condition various TTs are presented in Table 1 (symbols "+" or "-" denote that the feature on the left either characterizes the languages under discussion or not; pr. = predominantly; $>[<]$ mean "is more [less] productive or manifold")).

The majority of Russian $\rightarrow$ English TTs conditioned by typological differences are rather trivial, as, for instance, addition of auxiliary verbs, articles, personal and possessive pronouns in English translations.

The case of pronoun-drop in Russian and its impossibility in English is illustrated in example (4):
(4) $D a$
ved'
ne
really
not
primet
$[\varnothing=$ ona "she" $]$ / [Ø = menja "me"
]. [LT]
and
ot admit.FUT.3SG

a. But you know she won't see me (Car-6);

Table 1. Typological features of English and Russian

\begin{tabular}{|l|l|l|l|}
\hline & \multicolumn{1}{|c|}{ Russian } & \multicolumn{1}{c|}{ English } & \multicolumn{1}{c|}{$\begin{array}{c}\text { Type of Russian } \rightarrow \\
\text { English TTs }\end{array}$} \\
\hline 1. Word order & Free & fixed (SVO) & Permutation \\
\hline 2. Tense-aspect-mood forms & pr. Synthetic & pr. Analytic & Addition \\
\hline 3. Inflectional potential & Rich & Poor & Omission \\
\hline 3.1. Cases in nouns & + & - & Omission \\
\hline 3.2. Gender in nouns & + & - & Omission \\
\hline 4. Case-Gender-Number Agreement & + & - & Omission \\
\hline 5. Pronoun-drop & + & - & Addition \\
\hline 6. Articles & - & + & Addition \\
\hline 7. Possessive constructions & byt' (be) & have & construction change \\
\hline 8. Non-canonical Subject marking & + & - & construction change \\
\hline
\end{tabular}


Table 2. Contrastive features of English and Russian

\begin{tabular}{|c|c|c|c|}
\hline & Russian & English & $\begin{array}{c}\text { Type of Russian } \rightarrow \\
\text { English TTs } \\
\end{array}$ \\
\hline 1. Actant derivation & postfix -sja & - & construction change \\
\hline 1.1. Labile verbs & - & + & construction change \\
\hline 1.2. Ø-causation & - & + & construction change \\
\hline 1.3. Ø-detransitivization & - & + & construction change \\
\hline 2. Contrast / Focus means & Particles & clefting; raising & construction change \\
\hline 3. Impersonal passive & + & - & construction change \\
\hline 4. Noun (attr.) + Noun & - & + & construction change \\
\hline 5. Noun $\rightarrow$ Verb conversion & - & + & construction change \\
\hline 6. Verb $\rightarrow$ Noun conversion & - & + & construction change \\
\hline 7. Modal verbs & Few & Many & Addition \\
\hline 8. Causative verbs & Few & Many & Addition \\
\hline 9. Phrasal verbs & - & + & construction change \\
\hline 10. Prefixal-postfixal verbs & + & - & construction change \\
\hline $\begin{array}{l}\text { 11. Different-Sb converbal } \\
\text { constructions }\end{array}$ & - & + & construction change \\
\hline 12. Personal passive & \multicolumn{2}{|l|}{$<$} & construction change \\
\hline 13. Infinitival constructions & \multicolumn{2}{|l|}{$>$} & construction change \\
\hline 14. Possessor raising & \multicolumn{2}{|l|}{$>$} & construction change \\
\hline 15. Negation & poly- & mono- & Omission \\
\hline 16. Verbal prefixation & pr. spatial & pr. evaluative & Addition \\
\hline
\end{tabular}

b. But she would not see me (Ed-18);

c. But she won't see me (Gar-6; Mag-10);

d. But she won't admit me! (LAM-5; PV-6; Wet-25).

The list of contrastive features differentiating Russian from English is much longer and comprises at least the following properties (some of these may be also considered in other classifications as rather typological and not only contrastive) (Table 2).

\section{English correspondences}

\section{of Russian constructions lacking the nominative subject}

Below I present the main translational equivalents of Russian constructions which lack the nominative subject: 1) impersonal constructions proper, 2) indefinite-subject constructions, 3) genericsubject constructions, 4) dative-subject modal constructions, 5) infinitival constructions, and 6) constructions with the preposition $\boldsymbol{u}$. It should be noted that in the typological volume "Impersonal Constructions" (Malchukov \& Siewierska, 2011) all these types of constructions by definition belong to the domain of impersonal constructions whereas Russian grammatical tradition distinguishes at least three main types of subjectless constructions (only the first of them is considered as impersonal in Russian grammars): 
1) impersonal constructions proper allowing no subject in the nominative case (these constructions are formed by means of at least two dozen syntactic patterns and may express at least a dozen different meanings),

2) indefinite personal (neopredeljonno-ličnyje) constructions, e.g.
(5) $V$
dver'
po-stuča-1-i.
In
door
PREF-knock-PAST-PL

Somebody knocked on the door And

3) generic personal (obobščonno-ličnyje) constructions, e.g.
(6) Tsypljat
po
Oseni
sčita-jut (a proverb).
chicken.3PL.ACC
in
autumn
count-PRES.3PL

Chickens are counted in autumn.

Under the definition of impersonality taken in the volume "Impersonal Constructions" (2011) all Russian constructions of these types (and many others) fall into the domain of impersonality. Needless to say, all such constructions are translated into English by means of changing the syntactic structures.

\subsection{Impersonal constructions proper}

It is difficult to compare English and Russian impersonal constructions (ICs) because they are characterized in these languages by different formal and semantic features. ICs in Russian have the following properties: 1) they can't have the nominative subject, 2) they can include only predicates in the $3^{\text {rd }}$ person singular (and only in the neutral gender in the past tense), whereas the verb forms in the $1^{\text {st }}$ and $2^{\text {nd }}$ persons are lacking (and in the past tense both the masculine and feminine forms are also lacking), e.g. Sveta-jet "Morning is coming" (*Sveta-ju [1SG] / *Sveta-ješ [2SG]); Menja [I-ACC] znobi-l-o [NEUTR] "I felt fever" (*znobi-l-a [FEM] / *znobil (MASC]). English ICs as a rule use the impersonal pronoun it.

The possible basis for the comparison of ICs in English and Russian may be the absence of active Agent in the semantic structure of the constructions under analysis.

There are at least four main syntactic types of ICs in Russian:

1) ICs involving strictly impersonal verbs (Smerka-jet-sja "It's getting dark");

2) ICs involving personal verbs in the impersonal usage (Uragan-om [INSTR] so-rva-l-o kryš- $u$ $[\mathrm{ACC}]$ "The roof was blown off by the hurricane");

3) ICs involving predicative adverbs ( $E j$ [she-DAT] xolod-no "She feels cold");

4) ICs involving negative words net "not", ne by-l-o "no-PAST", ne bud-et "no-FUTURE" $(U$ menja [I-GEN] net vremeni [time-GEN] "I have no time").

The productivity of these types of lexical means is given in specialist literature as follows: there are about 120 strictly impersonal verbs, about one thousand verbs which can be used both personally and impersonally [Korol'kova 1980], and more than one thousand predicative adverbs in -(n)o [Bojko 1998]. 
In Russian there are about ten semantic types of situations which can be expressed by ICs:

1) ICs denoting natural phenomena (mainly involving weather verbs);

2) ICs denoting physiological states;

3) ICs denoting situations of sense perception;

4) ICs denoting emotions and feelings;

5) ICs expressing evaluation of situations;

6) ICs denoting states of affairs (mainly with perfect or resultative meanings);

7) ICs denoting absence or shortage of something;

8) ICs denoting mental states;

9) ICs expressing deontic modality;

10) ICs expressing potential modality.

The main ways of translating Russian ICs into English are the following: 1) English personal constructions, 2) English constructions involving dummy it, 3) English constructions involving introductory element there, 4) English constructions involving introductory element one.

Below I provide some examples for the main semantic types of Russian ICs.

\subsubsection{ICs denoting natural phenomena}

There are two main patterns which express these meanings: one involving the dummy subject $\boldsymbol{i t}$, and the other involving the introductory phrases there was / there is. In all examples below Russian ICs contain the verb byt' 'to be' in the neutral gender, e.g.

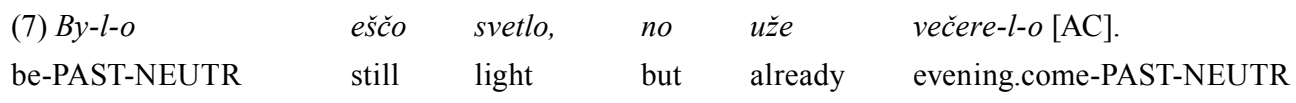

It was still light, but beginning to get dark;

$\begin{array}{llllll}\text { (8) } O t & \text { okn- } a & \text { by-l-o } & \text { xolodno } & i & \text { syro [AC]. } \\ \text { from } & \text { window-GEN } & \text { be-PAST-NEUTR } & \text { Cold } & \text { and } & \text { Damp }\end{array}$

There was a cold damp draught from the window, however;

$\begin{array}{lllllll}\text { (9) ...no } & \text { kak-to } & \text { osobenno } & \text { dušno } & \text { by-l-o } & v & \text { vozdux-e [FD]. } \\ \text { but } & \text { somehow } & \text { especially } & \text { stuffy } & \text { be-PAST-NEUTR } & \text { in } & \text { air-LOC }\end{array}$

...but there was a peculiar breathlessness in the air.

It should be noted that all constructions of this type not only express natural phenomena but also imply perception of these states by the humans involved in the situation.

\subsubsection{ICs denoting physiological states}

Russian ICs of this type are often translated by English personal constructions which include the verb "feel" (see examples (11) and (12)). In Russian constructions we find the non-canonical subject marking (either in the dative or in the accusative case), whereas English correspondences contain the nominative pronominal subjects, e.g.
(10) Ego
sta-l-o
znobit' [AC].

he-ACC

begin-PAST-NEUTR shiver

....and he began to shiver; 
(11) $\mathrm{Na}$ tak-oj žar-e emu stanovi-l-o-s' xolodno [FD].

on that-LOC heat-LOC he-DAT become-PAST-NEUTR-POST Cold

In spite of the heat he felt cold;

(12) Emu stuknu-l-o v golov-u $i \quad$ potemne-l-o vlaz-ax [FD].

he-DAT strike-PAST-NEUTR in head-ACC and become.dark-PAST-NEUTR in eye-LOC.PL

He felt a hammering in his head, and there was a darkness before his eyes.

Peripheral TT is represented by the addition of a causative verb make, cf.:

\subsubsection{ICs denoting emotions and feelings}

English personal constructions as in the previous case are the predominant translational equivalents of Russian ICs of this type. The verb "feel" as in the previous case is as a rule added in English translations, e.g.

(14) No teper' ego vdrug potjanu-l-o $\quad k \quad$ ljud-jam [FD]. but now he-ACC suddenly draw-PAST-NEUTR to people-DAT.PL

But now all at once he felt a desire to be with other people // ...but now he suddenly felt drawn to people;

(15) Emu sta-l-o protivno [FD].

he-DAT become-PAST-NEUTR disgusting

He felt disgusted.

In Chekhov's plays such emotions as skuka "boredom”, grust' "depression”, želanije "wish" are very often expressed, e.g.

(16) Skučno

boring

He bores me. $\begin{array}{ll}s & \operatorname{nim}[\mathrm{AC}] . \\ \text { with } & \text { he.INSTR }\end{array}$

\subsubsection{ICs denoting situations of sense perception}

English translations rather often contain the verb can:

(17) $V$ dom-e slyšno [AC].

in home-LOC can.be.heard

They can hear you;

(18) ...pah-l-o izvest'-ju, pyl'-ju, stojače-ju vod-oj [FD].

smell-PAST-NEUTR mortar-INSTR dust-INSTR stand-INSTR water-INSTR

There was a smell of mortar, dust and stagnant water.

English passive constructions are also registered in this case:

(19) Sta-l-o

become-PAST-NEUTR

The room was filled with noise. šumno [FD].

noisy 


\subsubsection{ICs expressing modal meanings}

English translations of this type usually contain the indefinite pronoun one and the modal verb can, e.g.
(20) Možno by-l-o
dogadat'-sja... [AC].
Possible
be-PAST-NEUTR
guess-POST.INF

One could see (that...);

$\begin{array}{llllllll}\text { (21) } D a & \text { ved' } & \text { nel'zja } & \check{z} e & \text { molčat', } & \text { kogda } & \text { čuvstvu-ješ } & \text { (čto..) [FD] } \\ \text { but } & \text { CLT } & \text { impossible } & \text { CLT } & \text { keep.silence.INF } & \text { when } & \text { feel.PRES-2SG } & \text { (that...) }\end{array}$

Well, one can't hold one's tongue when one has a feeling...

Other types of TTs of Russian constructions lacking the nominative subject are presented below with short comments.

\subsection{Indefinite-subject constructions}

Such Russian constructions containing the main predicate in the $3^{\text {rd }}$ person (past tense and plural number) are often translated by English passive constructions, although active constructions with the subjects they, people, someone, everyone and those were also registered, e.g.

$\begin{array}{llllll}\text { (22) Stiva, } & k a k & \text { ego } & z v a-l-i & v & \text { svet-e... (LT) } \\ \text { Stiva } & \text { as } & \text { he.ACC } & \text { call-PAST-PL } & \text { in } & \text { society-LOC }\end{array}$

a. Stiva, as he was called in society (Car-1; Gar-1; LAM-1; PV-1);

b. Stiva, as he was generally called by his friends (Ed-13; Mag-5);

c. "Stive" as he was known to his friends in the fashionable world (Wet-19);

(23) $O t$

$$
\text { xozjain-a- }
$$

izvozčik-a

prixodi-l-i (LT).

From

master-GEN

cabman-GEN

come-PAST-PL
a. They've sent someone from the livery stables (Car-4);
b. They've sent from the carriage-jobbers (Gar-4);
c. Someone came from the livery-stables (Ed-16; Mag-9; PV-4);
d. Someone has called from the jobmaster's (LAM-4);
e. The stable-owner's man was here (Wet-23);

$\begin{array}{llllll}\text { (24) } D a & \text { posla-l-i } & l i & z a & \text { svež-im } & \text { moloko-m? (LT) } \\ \text { CLT } & \text { send-PAST-PL } & \text { CLT } & \text { for } & \text { fresh-INSTR } & \text { milk-INSTR }\end{array}$

a. Have you sent for fresh milk? (PV-14; Wet);

b. But has the fresh milk been sent for? (Car-14; Ed-26; LAM-13);

c. But did you send for some new milk? (Gar-16);

d. And the fresh milk? Has it been sent for? (Mag-19). 


\subsection{Generic-subject constructions}

Russian constructions of this type contain the main predicate in the $2^{\text {nd }}$ person singular number or $3^{\text {rd }}$ person plural number (see (6)). Variation of means of translation of Russian generic-subject constructions is presented in English examples below:

$\begin{array}{lcclcccl}\text { (25) Mnogo } & \text { tam } & \text { eščo } & \text { by-l-o } & \text { otličn-ogo, } & \text { da } & \text { ne } & \text { skaž-eš } \\ \text { much } & \text { there } & \text { still } & \text { be-PAST-NEUTR } & \text { special-GEN } & \text { CLT } & \text { not } & \text { say.FUT-2SG } \\ \text { slov-a-mi } & & i & \text { mysl-jami } & \text { daže } & \text { najavu } & \text { ne } & \text { vyrazi-š (LT). } \\ \text { word-PL-INSTR } & \text { and } & \text { thought-PL.INSTR } & \text { even } & \text { awake } & \text { not } & \text { express.FUT-2SG }\end{array}$

a. ...only there's no putting it into words, or even expressing it in one's thoughts awake (Gar-2);
b. ... which I can't just get hold of - can't catch now I'm awake (LAM-2);
c. ... but it can't be put into words, or expressed in thoughts, now that I am awake (Mag-6; Ed$14)$;

d. ...but one can't say it in words, or even put it into waking thoughts (PV-2);

e. ...but you can't put it all into words or even thoughts, can't express it when you wake up (Wet20; Car-2).

\subsection{Dative-subject constructions}

There are several semantic types of dative subject constructions mainly expressing emotional or psychological states. Main predicates in the neutral gender past tense are predominant means of translation. I illustrate here the perfect and the modal subtypes:

$\begin{array}{lllllll}\text { (26) ...emu } & \text { zaxvati-l-o } & \text { dyxanije, } & \text { čto-to } & \text { podstupi-l-o } & k & \text { gorl-u (LT). } \\ \text { he.DAT } & \text { catch-PAST-NEUTR } & \text { breath.ACC } & \text { something } & \text { come-PAST-NEUTR } & \text { to } & \text { throat-DAT }\end{array}$
a. ...he gasped, a lump rose up in his throat / his throat choked up with sobs (Car-11; LAM-10);
b. ...he caught his breath, lump rose in his throat... the sobs choked him (Ed-23; Mag-16);
c. ...he caught his breath, lump rose in his throat, he was choked by sobs (Wet-32);
d. ...there was a catch in his breath and a lump in his throat, there was a sob in his throat (Gar$13)$;

e. ...his breath failed him, something rose in his throat... sobs caught in his throat (PV-11);

$\begin{array}{lllll}\text { (27) ...emu } & \text { by-l-o } & \text { nevyrazimo } & \text { žalko } & \text { ejo (LT). } \\ \text { he.DAT } & \text { be-PAST-NEUTR } & \text { inexpressibly } & \text { pity } & \text { she-ACC }\end{array}$

a. He felt unutterably sorry for her (Ed-24; Wet-32; PV-11);

b. He felt inexpressibly sorry for her (Mag-17; Car-12; LAM-11);

c. He was unutterably sorry for her (Gar-14).

Modal meanings are as a rule expressed by means of such Russian modal adverbs as nužno / nado "necessary". Non-canonical subject marking in Russian constructions is changed to nominative pronominal subjects, e.g. 
(28) ...mne

I-DAT ěšco

still nado

necessary sjezdit' (LT).

go.INF

a. I have got to go on somewhere else (Gar-23);

b. I have to go somewhere else (LAM-18; Car-20; Ed-32; Mag-26);

c. I still have to go somewhere (PV-19);

d. I have to make a call (Wet-42);

(29) No

but mne

I.DAT пužno

necessary $b y-l-o$

be-PAST-NEUTR you.ACC videt' (LT).

see.INF

a. But I wanted to see you (Ed-31; Gar-23);

b. But I want to see you (LAM-18);

c. But I have to see you about something (Mag-25);

d. But I had to see you (PV-18; Car-19);

$\begin{array}{llllllll}\text { (30) Ved' } & \text { mne } & \text { očen', } & \text { očen' } & \text { nužno } & \text { pogovorit' } & s & \text { toboju }(\mathrm{LT}) \text {. } \\ \text { really } & \text { I.DAT } & \text { very } & \text { very } & \text { necessary } & \text { speak.INF } & \text { with } & \text { you.INSTR }\end{array}$

a. I really must talk to you (Car-20; Wet-42);

b. You know, I must have a talk with you (Ed-31; Mag-26);

c. You know, I want very much to talk to you (Gar-23);

d. You know, it is very, very important for me to have a talk with you (LAM-18);

e. Now, I must speak to you (Wet-42);

f. I need very, very much to have a talk with you (PV-19).

\subsection{Infinitival constructions}

The majority of Russian infinitival constructions imply various modal meanings, which become explicitly expressed in English translations which often exhibit variation of modal verbs and voice forms (either active or passive; see examples (32)), (33) and (34)), e.g.

$\begin{array}{lllllll}\text { (31) Pojti } & \text { ili } & \text { ne } & \text { pojti? }- & \text { govori-l } & \text { on } & \text { sebe (LT). } \\ \text { go.INF } & \text { or } & \text { not } & \text { go.INF } & \text { say-PAST.MASC } & \text { he } & \text { himself.DAT }\end{array}$

a. Should I see her now or not? (Car-9);

b. Shall I go and see her or not? (Ed-21);

c. To go, or not to go? (LAM-9; Gar-11; Mag-15);

d. Shall I go or not? (PV-9);

e. To go to her or not? (Wet-29);

$\begin{array}{lllll}\text { (32) Čto } & \text { nadet } & \text { det-jam } & n a & \text { guljanje? (LT) } \\ \text { what } & \text { put.on.INF } & \text { children-PL.DAT } & \text { on } & \text { walk }\end{array}$


a. What walking clothes should the children put on? (Car-14);

b. How were the children to be dressed for their walk? (Ed-25 / 26);

c. What were the children to put on for their walk? (Gar-16; Wet-34 / 35);

d. What should the children wear when they went out? (LAM-13);

e. How are the children to be dressed for their walk? (Mag-19);

f. ...what should the children wear for their walk? (PV-13);

(33) ...davat'

give.INF li

CLT moloko? (LT)

milk.ACC

a. Ought they to have some milk? (Car-14);

b. Ought they to have any milk? (Ed-26; Mag-19);

c. Ought they to have milk? (LAM-13);

d. Should they have milk? (PV-13; Gar);

e. Were they to be given milk? (Wet-35);

(34) No

but

čto $\quad \check{z} e$

what

CLT

$$
[\varnothing=\text { mne "I-DAT] }
$$

delat'?

do.INF

čto

what

delat'? (LT)

do.INF
a. But what can I do? What is there to do? (Car-3);
b. But what is to be done? What can I do? (Ed-15);
c. But what's to be done? What's to be done? (Gar-3; Mag-7; Wet-21);
d. But what am I to do? What can I do? (LAM-3);
e. But what to do, then? What to do? (PV-3).

Addition of two English personal pronouns is found in the example below:

$\begin{array}{lllllll}\text { (35) } \mathrm{Ni} & \text { popljasat', } & n i & \text { pogovorit', } & n i & \text { vypit' } & \text { tolkom [AC]. } \\ \text { not } & \text { dance.INF } & \text { not } & \text { talk.INF } & \text { not } & \text { drink } & \text { seriously }\end{array}$

You can’t dance, or talk, or drink with them.

\subsection{Constructions with the preposition " $u$ "}

English personal constructions are the only way to translate Russian $u$-constructions, e.g.

$\begin{array}{llllllllll}\text { (36) [on] } & \text { radostno } & \text { ulybnu-l-sja } & \text { ne } & \text { ottogo, čtob } & u & \text { nego } & n a & \text { duš-e } \\ \text { [he] } & \text { happily } & \text { smile-PAST-POST not } & \text { because that } & \text { at } & \text { he-GEN } & \text { on } & \text { soul-LOC } \\ \text { by-l-o } & & \text { čto-nibud' osobenno } & \text { prijatnoje (LT). } \\ \text { be-PAST-NEUTR } & \text { anything especially } & \text { pleasant }\end{array}$

a. ... [he] smiled happily but not because he felt particularly pleased (Mag-13; Ed-20);

b. ... [he] smiled joyfully, not because there was anything specially pleasant in his mind (LAM-7; Car-8; Gar-9; PV-3; Wet-28). 
The main ways of translating Russian ICs into English are the following: 1) English personal constructions, 2) English constructions involving dummy it, 3) English constructions involving introductory element there, 4) English constructions involving introductory element one. Additional research of English translational variants of Russian impersonal constructions is needed which will make it possible to reveal all types of Russian $\rightarrow$ English syntactic and lexical transformations conditioned by both typological and contrastive differences of these languages. Anna Wierzbicka put forward the idea that Russian impersonal constructions which are probably developed to the greatest degree in comparison with other European languages can be interpreted as the consequence of non-controllability of feelings and irrationality of Russian mentality (Vezhbickaya, 1996: 44-45; 73-74). It seems to be a far-fetched conclusion since non-canonical subject marking, productivity of neutral gender verb forms, abundance of infinitival constructions and implicit expression of psychological and physiological states (which leads to the appearance of English verbs feel, can and make in translated texts) are hardly conditioned by the characteristics of Russian mentality.

\section{References}

Barkhudarov, L. S. Jazyk i perevod. [Language and translation]. Moscow: Meždunarodnye otnošenija, 1975.

Bojko, A. A. Slovar'-spravočnik. Predicativnyje infinitivnyje sočetanija v sovremennom russkom jazyke [A Dictionary-Reference Book. Predicative Infinitival Constructions in Contemporary Russian]. St.Petersburg: Razumova Publishing House, 1998.

Korol'kova, A. V. K leksiko-grammatičeskoj xarakteristike bezličnyx form glagola i ix funktsyonirovanija [Lexical-grammatical characteristics of impersonal verb forms and their functioning]. Funktsional'nyj analiz grammatičeskix jedinits [Functional analysis of grammatical units]. Leningrad, 1980.

Malchukov, A. \& Siewierska, A. (eds.). Impersonal Constructions: A cross-linguistic perspective. (Studies in Language Companion Series 124). Amsterdam \& Philadelphia, John Benjamins, 2011.

Novikov, L. (ed.). Sovremennyj russkij jazyk. [Modern Russian]. St.Petersburg: Lan’, 1999.

Vezhbickaya, A. [Wierzbicka Anna]. Jazyk, Kul'tura, Poznanije [Language. Culture. Cognition]. Moscow, Russkije slovari [Russian Dictionaries], 1996.

\section{Sources and Abbreviations}

AC - Anton Chekhov. Sobranije sochinenij [Collection of Works]. Volume 9. Plays. Moscow. 1963.

FD - Fyodor Dostoyevsky. Prestuplenije i nakazanije [Crime and Punishment]. Leningrad. 1977.

LT — Lev Tolstoy. Anna Karenina. Moscow. 1979.

Car - Anna Karenina by Leo Tolstoy. The modern American translation by Joel Carmichael. Bantam Books. New York. 1960.

Gar - Leo Tolstoy. Anna Karenina. Translated by Constance Garnett. Release Date: April 2, 2005 (www.gutenberg.net).

Ed - Leo Tolstoy. Anna Karenin. Translated by Rosemary Edmonds. Penguin Classics. 1954. 
LAM — Leo Tolstoy. Anna Karenina. Translated by Louise \& Aylmer Maude. Wordsworth Classics. 1999.

Mag — Leo Tolstoy. Anna Karenina. Translated by David Magarshack. Signet Classic. New York. 1961.

PV — Leo Tolstoy. Anna Karenina. Translated by Richard Pevear and Larissa Volokhonsky. Penguin Books. London. 2006.

Wet - Leo Tolstoy. Anna Karenina. Translated by Margaret Wettlin. Progress Publishers. Moscow. 1978.

\section{List of Abbreviations}

\begin{tabular}{|c|c|}
\hline $1,2,3$ & person \\
\hline ACC & accusative case \\
\hline CLT & clitic \\
\hline DAT & dative case \\
\hline FEM & feminine gender \\
\hline GEN & genitive case \\
\hline INF & infinitive \\
\hline INSTR & instrumental case \\
\hline LOC & locative case \\
\hline MASC & masculine gender \\
\hline NEUTR & neutral gender \\
\hline PAST & past tense \\
\hline PL & plural number \\
\hline POST & postfix \\
\hline PREF & prefix \\
\hline PRES & present tense \\
\hline SEMELF & semelfactive aspect \\
\hline SG & singular number \\
\hline
\end{tabular}




\title{
Типологические и контрастивные черты русского и английского языков \\ и переводческие трансформации
}

\section{И.В. Недялков}

Санкт-Петербургский государственный университет Россия, 199034, Санкт-Петербург, Университетская наб., 7/9

\begin{abstract}
Английский и русский языки в значительной мере характеризуются диаметрально противоположными типологическими и контрастивными характеристиками по отнотению к таким признакам, как порядок следования главных членов предложения, синтетизм / аналитизм глагольных форм, флективный потенциал, падежность и род у существительных, согласование по лииу, числу, роду сказуемого с подлежащим, возможность опущения личных местоимений (pronoun-drop), артиклевость, неканоническое маркирование подлежащего, способы актантной деривации и ряду других языковых признаков. Все они обусловливают при русско-английском переводе те или иные переводческие трансформации различных типов. Последние рассматриваются на материале нескольких английских переводов произведений русской классики. В статье приводятся английские соответствия русских бесподлежашных конструкиий, в том числе безличных предложений различных семантических и синтаксических типов, дативных и инфинитивных конструкций. Приводятся основные типы английских переводческих соответствий подобных русских конструкиий.
\end{abstract}

Ключевые слова: теория перевода, лингвистическая типология, контрастивная лингвистика, типологические и контрастивные характеристики английского и русского языков, переводческие трансформацчи, безличные конструкичи, инфинитивные конструкичи, английские средства выражения.

Научная специальность: 10.00.00 - филологические науки. 